\title{
Zinc Bromide Combustion: Implications for the Consolidated Incinerator Facility
}

by

L. N. Oji

Westinghouse Savannah River Company

Savannah River Site

Aiken, South Carolina 29808

DOE Contract No. DE-AC09-96SR18500

This paper was prepared in connection with work done under the above contract number with the U. S. Department of Energy. By acceptance of this paper, the publisher and/or recipient acknowledges the U.S. Government's right to retain a nonexclusive, royalty-free license in and to any copyright covering this paper, along with the right to reproduce and to authorize others to reproduce all or part of the copyrighted paper. 


\section{DISCLAIMER}

This report was prepared as an account of work sponsored by an agency of the United States Government. Neither the United States Government nor any agency thereof, nor any of their employees, makes any warranty, express or implied, or assumes any legal liability or responsibility for the accuracy, completeness, or usefulness of any information, apparatus, product, or process disclosed, or represents that its use would not infringe privately owned rights. Reference herein to any specific commercial product, process, or service by trade name, trademark, manufacturer, or otherwise does not necessarily constitute or imply its endorsement, recommendation, or favoring by the United States Government or any agency thereof. The views and opinions of authors expressed herein do not necessarily state or reflect those of the United States Government or any agency thereof.

This report has been reproduced directly from the best available copy.

Available to DOE and DOE contractors from the Office of Scientific and Technical Information, P. O. Box 62, Oak Ridge, TN 37831; prices available from (423) 576-8401.

Available to the public from the National Technical Information Service, U. S. Department of Commerce, 5285 Port Royal Road, Springfield, VA 22161. 


\section{DISCLAIMER}

Portions of this document may be illegible in electronic image products. Images are produced from the best available original document. 
WESTINGHOUSE SAVANNAH RIVER COMPANY

SAVANNAH RIVER TECHNOLOGY CENTER

ZINC BROMIDE COMBUSTION: IMPLICATIONS FOR THE CONSOLIDATED INCINERATOR FACILITY (U).

Author: Lawrence N. Oji

Report Date: October 28, 1998

Westinghouse Savannah River Company Savannah River Site

Aiken, SC 29808

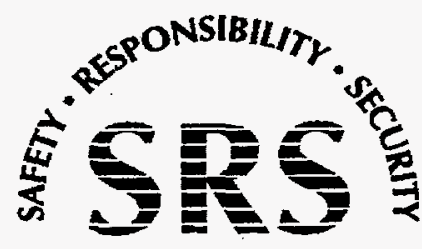


WESTINGHOUSE SAVANNAH RIVER COMPANY

SAVANNAH RIVER TECHNOLOGY CENTER.

ZINC BROMIDE COMBUSTION: IMPLICATIONS FOR THE

CONSOLIDATED INCINERATOR FACILITY (U).

Author

Lawrence Oji, Waste Processing Technology

Date

Design Check

Barnes, Mark J.

Date

Approvals/Review

B.T. Butcher, Level 4 Manager, Waste Processing Technology

Date

Westinghouse Savannah River Company

Savannah River Site

Aiken. SC 29808

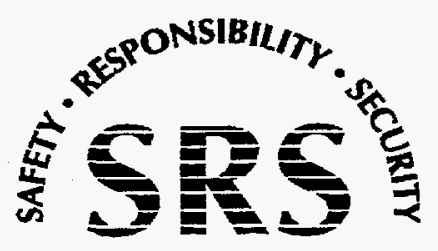




\title{
WESTINGHOUSE SAVANNAH RIVER COMPANY SAVANNAH RIVER TECHNOLOGY CENTER.
}

\author{
Keywords: Bromine, Bromides of Zinc \\ Zinc Oxide, Zinc Carbonate \\ "Blowdown", Quench, \\ Sodium Bromide.
}

\section{ZINC BROMIDE COMBUSTION: IMPLICATIONS FOR THE} CONSOLIDATED INCINERATOR FACILITY (U).

\section{Summary}

A review of literature on the implications of burning zinc bromide in the Consolidated Incinerator Facility (CIF) has been conducted. In excess air, zinc bromide will decompose at CIF operating temperatures to yield bromine gas, zinc oxide/carbonate precipitates, zinc bromate, and other bromine derivatives. An effective bromine scrubbing system will be needed in that case to capture all the bromine/bromic acid gases and satisfy regulatory requirements for operating the CIF. Bromine gas will corrode stainless-steel parts of a furnace, so corrosion resistant materials would be required.

Zinc oxide $(\mathrm{ZnO})$, which is one of the principal zinc bromide combustion products, will end up as bottom ash product in the CIF. Depending on its particle size, zinc oxide will also contribute to the suspended solids in the off-gas system and may eventually end up in the HEPA (High Efficiency Particulate Air) filter system. Sodium bromide (NaBr) produced from the quenching of bromine gas and its hydrogenated derivatives with caustic is expected to remain in the scrubber solution.

On a basis of 45.36 kilogram (100 lbs.) of zinc bromide combusted, the estimated quantity of bromine gas and zinc oxide produced are approximately $32 \mathrm{~kg}$ and $16 \mathrm{~kg}$, respectively. If we assume a $100 \%$ efficiency in the conversion of bromine to sodium bromide in the caustic neutralization of acidic vapors using the steam atomized scrubber system, approximately $51 \mathrm{~kg}$ of sodium bromide will be produced.

Lacking plant experience involving thermal decomposition of zinc bromide, trial burn tests will be needed to determine the following: 
- The most appropriate zinc bromide-to-fuel oils and air mixture ratio, that will sustain complete combustion of zinc bromide.

- Difficulties of scrubbing zinc oxide/carbonate insoluble salts during quenching and "blowdown" operations.

- The performance of the HEPA filter systems (measured as drops in pressure) in the presence of fine particles of zinc oxide and zinc carbonate.

- True quantity of secondary and primary combustion products.

Prior to selecting combustion of zinc bromide in the CIF, Solid Waste should identify the specific treatment objective for zinc bromide backed up with a full characterization of the wasteform. Alternative treatment options for zinc bromide need to be investigated. A treatability study may also be needed to evaluate the most promising treatment option identified. Solid Waste should also determine how other Department of Energy (DOE) sites dispose of zinc bromide.

\section{INTRODUCTION}

In the nuclear industry, zinc bromide $\left(\mathrm{ZnBr}_{2}\right)$ is used for radiation shielding. At Savannah River Site (SRS) zinc bromide solution, in appropriate configurations and housings, was used mainly for shielding in viewing windows in nuclear reactor and separation areas. Waste stream feeds that will be incinerated at the CIF will occasionally include zinc bromide solution/gel matrices.

The CIF air pollution systems control uses a water-quench and steam atomizer scrubber that collects salts, ash and trace metals in the liquid phase. Water is re-circulated in the quench unit until a predetermined amount of suspended solids or dissolved salts are present. After reaching the threshold limit, "dirty liquid", also called "blowdown", is pumped to a storage tank in preparation for treatment and disposal. The air pollution control system is coupled to a HEPA pre-filter/filter unit, which removes particulate matter from the flue gas stream (1).

The objective of this report is to review existing literature data on the stability of zinc bromide $\left(\mathrm{ZnBr}_{2}\right)$ at $\mathrm{CIF}$ operating temperatures $\left(>870^{\circ} \mathrm{C}\left(1600{ }^{\circ} \mathrm{F}\right)\right)$ and determine what the combustion products are in the presence of excess air. The partitioning of the combustion products among the quench/scrubber solution, bottom ash and stack will also be evaluated. In this report, side reactions between zinc bromide and its combustion products with fuel oil were not taken into consideration.

\section{ZINC BROMIDE INCINERATION}

At the CIF, a zinc bromide/fuel oil mixture would be introduced into a primary furnace operating at about $870^{\circ} \mathrm{C}\left(1600^{\circ} \mathrm{F}\right)$. The combustion products are directed to a secondary furnace at about $980-1010^{\circ} \mathrm{C}\left(1800-1850^{\circ} \mathrm{F}\right)$. The last step involves the use of a water quencher (temperature is reduced to about $80^{\circ} \mathrm{C}\left(180^{\circ} \mathrm{F}\right)$ and steam atomized scrubber which collects salts, ash and traces of metals in the liquid phase. In this step sodium hydroxide is added in two locations in the off-gas system to control $\mathrm{pH}$ ( $\mathrm{pH} 4.5-9$ ). The 
caustic is added to the quench tank and directly into the steam atomized scrubber to neutralize acidic gas carryover out of the quench.

\section{Zinc Bromide Incineration in Excess Air}

In excess air, zinc bromide will start to decompose at a temperature of about $700{ }^{\circ} \mathrm{C} \mathrm{(2).}$ See Appendix A. The primary gaseous products of zinc bromide combustion in excess air are bromine gas and bromic acids (see summary in Table 1). Fine particles of insoluble zinc oxide and zinc carbonate are the principal solid combustion products of zinc bromide $(3,4$, and 5$)$. Sodium bromide produced from the bromine quenching reactions with sodium hydroxide in the off-gas system is expected to be the main soluble salt in the scrubber solution. $\mathrm{Zinc}$ bromate $\left(\mathrm{Zn}\left(\mathrm{BrO}_{3}\right)_{2} .6 \mathrm{H}_{2} \mathrm{O}\right)$ and zinc hydroxide $\left(\mathrm{Zn}(\mathrm{OH})_{2}\right)$ may also be produced as a by-product of quenching reaction (5). A summary of some principal reactions at $\mathrm{CIF}$ temperatures greater than $700^{\circ} \mathrm{C}$ is shown below:

$$
\mathrm{ZnBr}_{2}+1 / 2 \mathrm{O}_{2} \rightarrow \mathrm{ZnO}_{(\mathrm{s})}+\mathrm{Br}_{2(\mathrm{~g})}
$$

$$
\mathrm{ZnBr}_{2}+1 / 2 \mathrm{O}_{2}+\mathrm{CO}_{2} \rightarrow \mathrm{ZnCO}_{3(\mathrm{~s})}+\mathrm{Br}_{2(\mathrm{~g})}
$$$$
\mathrm{ZnO}_{(\mathrm{s})}+2 \mathrm{HBr}-\cdots--\mathrm{HH}_{2} \mathrm{O} \rightarrow \mathrm{Zn}\left(\mathrm{BrO}_{3}\right)_{2} \cdot 6 \mathrm{H}_{2} \mathrm{O}_{(\mathrm{s})}
$$$$
\mathrm{Br}_{2}+\mathrm{H}_{2} \mathrm{O}-- \text { Quench temp.-- } \rightarrow \mathrm{HBr} \text { (vap.) } \mathrm{HBrO}_{\mathbf{x}} \text { (vap.) }
$$

Traces of hydrates of zinc bromides $\left(\mathrm{ZnBr}_{2} \bullet 2 \mathrm{H}_{2} \mathrm{O}\right.$ and $\left.\mathrm{ZnBr}_{2} \bullet 3 \mathrm{H}_{2} \mathrm{O}\right)$ are also possible by-products that may result from the quenching of hot gaseous phase components of the combustion of zinc bromide. These soluble by-products, including zinc bromate, zinc hydroxide and sodium bromide, will form the liquid salt phase or scrubber solution.

In the combustion of zinc bromide in excess air, bromine gas and bromic acid vapors are the main gaseous phase products. These gas phase products if not scrubbed will end up in the HEPA filters. Due to low solubility of zinc oxide and zinc carbonate in water, they are expected to be the principal solid phase products (bottom ash and fly ash). If the resulting oxides and carbonates of zinc formed are fine particles in the low micron size range, a white mist of these materials may be produced.

Bromine vapor and its gaseous derivatives will corrode stainless steel parts of the CIF equipment. Therefore, the CIF needs corrosion resistant parts to safely incinerate zinc bromide.

The quantitative estimation of primary combustion products for zinc bromide (bromine gas and zinc oxide) is based on equation (1) above:

One mole of zinc bromide in excess air will produce one mole of bromine gas and one mole of zinc oxide. This translates to 225.19 grams of zinc bromide producing 159.81 grams of bromine $\left(0.7097 \mathrm{~g}\right.$ of $\mathrm{Br} / \mathrm{g}$ of $\left.\mathrm{ZnBr}_{2}\right)$ and 81.4 grams of zinc oxide $(0.3615 \mathrm{~g}$ $\mathrm{ZnO} / \mathrm{g} \mathrm{ZnBr}_{2}$ ). 
On a basis of $45,360 \mathrm{~g}$ of $\mathrm{ZnBr}_{2}$ (100 lb. zinc bromide) combusted, the following amounts of primary combustion products will be produced:

Bromine

$\left(0.7097 \mathrm{~g} \mathrm{Br} / \mathrm{g}\right.$ of $\left.\mathrm{ZnBr}_{2}\right) *\left(45,360 \mathrm{~g} \mathrm{ZnBr}_{2}\right)=32,192 \mathrm{~g}$ or $32.192 \mathrm{~kg}$ of bromine gas.

\section{$\underline{\text { Zinc Oxide }}$}

$\left(0.3615 \mathrm{~g} \mathrm{ZnO} / \mathrm{g} \mathrm{ZnBr}_{2}\right)^{*}\left(45,360 \mathrm{~g} \mathrm{ZnBr}_{2}\right)=16,398 \mathrm{~g}$ or $16.398 \mathrm{~kg}$ of $\mathrm{ZnO}$.

Based on equation 1 above, $3.228 \mathrm{~kg}$ of oxygen would be consumed for this combustion of $45.36 \mathrm{~kg}$ of zinc bromide. In summary:

$$
\begin{aligned}
& \mathrm{ZnBr}_{\mathbf{2}}+\mathbf{1 / 2 \mathrm { O } _ { 2 }} \rightarrow \mathbf{Z n O}(\mathrm{s})+\mathrm{Br}_{\mathbf{2}}(\mathrm{g}) \\
& 45.36 \mathrm{~kg}+3.23 \mathrm{~kg} \quad 16.40 \mathrm{~kg}+32.20 \mathrm{~kg}
\end{aligned}
$$

If we assume that $100 \%$ of the bromine produced from the combustion of zinc bromide is converted into the sodium bromide salt during the addition of caustic (sodium hydroxide) to the off-gas system for $\mathrm{pH}$ control, then the amount of soluble sodium bromide can be estimated from a balanced equation for the reaction as shown below:

$$
2 \mathrm{Br}_{2}+4 \mathrm{NaOH} \rightarrow 4 \mathrm{NaBr}+2 \mathrm{H}_{2} \mathrm{O}
$$

\section{Sodium bromide}

Per equation 5 above, $32.20 \mathrm{~kg}$ of bromine gas is produced and per equation 6 two moles of bromine gas are needed to produce four moles of soluble sodium bromide salt; in other words, there is 1.57567 grams of sodium bromide per gram of bromine. Therefore, 50.74 $\mathrm{kg}$ of sodium bromide will be produced $\left(\left(1.57567 \mathrm{~g} \text { of } \mathrm{NaBr} / \mathrm{g} \mathrm{Br}_{2}\right)^{*}\left(32,200 \mathrm{~g} \mathrm{Br}_{2}\right)\right)$ if the starting basis for zinc bromide combustion is $45,360 \mathrm{~g}$ of $\mathrm{ZnBr}_{2}\left(100 \mathrm{lb} . \mathrm{ZnB}_{2}\right)$.

The estimation of quantitative amounts of secondary products like zinc bromate, zinc carbonate, hydroxides and others (equations $1-4$ ) is not quite as straightforward because their production rates in the course of the reactions are governed by so many other factors. So, their quantitative values can only be obtained in trial burns.

\section{Zinc Bromide Incineration in Limited Air}

If the zinc bromide-to-fuel and air ratio is not well established (insufficient air/oxygen), carbon or coke from the decomposing fuel oil will reduce zinc oxide to vapor phase elemental zinc at temperatures greater than $1000^{\circ} \mathrm{C}$ (see below). Metallic zinc vapor will become an off-gas product, which will adversely affect the functioning of the pollution control system of the CIF. 
$\mathrm{ZnO}_{(s)}+\mathrm{C}_{(\mathrm{s})} \rightarrow \mathrm{Zn}_{(\text {vap.) }}+\mathrm{CO}_{(\mathrm{g})}$ (reduction of zinc oxide in limited air).

Reduction of zinc is not spontaneous below the boiling point of zinc, and in the presence of other combustion products zinc will be re-oxidized as follows:

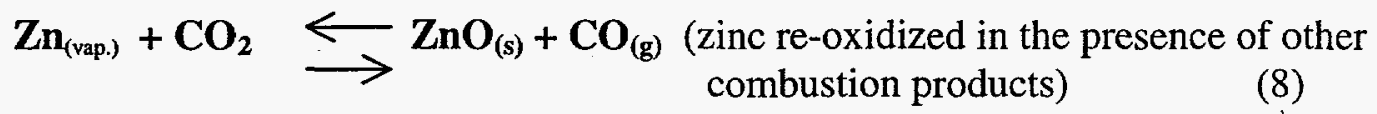

Therefore, to minimize the formation of vapor phase zinc metal, which will end up in the stack, the zinc bromide-to-fuel oil and air mixture must be optimized in a trial burn.

\begin{tabular}{|l|l|l|l|}
\hline CIF Operating Condition & \multicolumn{2}{|c|}{ Partitioning of Products } & \\
\hline & Scrubber Solution & $\begin{array}{l}\text { Bottom Ash/ } \\
\text { Quench Tank }\end{array}$ & HEPA Filters \\
\hline & & & \\
\hline & $\mathrm{NaBr}$ & $\mathrm{ZnO}$ & $\mathrm{Br}$ \\
\hline & $\mathrm{Zn}\left(\mathrm{OH}_{2}\right.$ & $\mathrm{ZnCO}$ & $\mathrm{HBr}$ (traces) \\
\hline & $\mathrm{Zn}\left(\mathrm{BrO}_{3}\right)_{2} \cdot 6 \mathrm{H}_{2} \mathrm{O}$ & & $\mathrm{HBrO}$ (traces) \\
\hline & $\mathrm{ZnO}$ & & \\
\hline & & & \\
\hline & & & \\
\hline Limited Air & $\mathrm{ZnO}$ & $\mathrm{ZnO}$ & $\mathrm{Zn}$ metal vapor \\
\hline & $\mathrm{Zn}\left(\mathrm{OH}_{2}\right.$ & $\mathrm{ZnCO}$ & $\mathrm{Br}$ \\
\hline & $\mathrm{NaBr}$ & & \\
\hline & $\mathrm{Zn}\left(\mathrm{BrO}_{3}\right)_{2} \cdot 6 \mathrm{H}_{2} \mathrm{O}$ & & $\mathrm{HBr}_{3}$ \\
\hline & $\mathrm{ZnBr}_{2} .2 \mathrm{H}_{2} \mathrm{O}$ & & $\mathrm{HBrO}_{x}$ \\
\hline & $\mathrm{ZnBr}_{2} \cdot 3 \mathrm{H}_{2} \mathrm{O}$ & & \\
\hline
\end{tabular}

Table 1. Zinc bromide combustion products and partitioning under excess and limited air-conditions in the CIF (main products are in bold characters).

\section{RECOMMENDATIONS}

The question must be asked, if one succeeds in converting approximately $45 \mathrm{~kg}$ of zinc bromide $\left(100 \mathrm{lb} . \mathrm{ZnBr}_{2}\right)$ into $50 \mathrm{~kg}$ of sodium bromide and $16 \mathrm{~kg}$ of zinc oxide including traces of bromine gas and others, what has really been gained?

Therefore, before embarking on the incineration of zinc bromide in the CIF Solid Waste should identify the specific treatment objective for zinc bromide and have zinc bromide wasteform fully characterized. Alternative treatment options for zinc bromide need to be investigated. A treatability study may also be needed to evaluate the most promising treatment option identified. Solid Waste should also determine how other Department of Energy (DOE) sites deal with zinc bromide. 
If the chosen treatment option is the combustion of zinc bromide in excess air using the $\mathrm{CIF}$, then the following will need to be addressed:

- A trial burn will have to be conducted to determine the particle size distribution of zinc oxide and zinc carbonate and the effects these particles may have on the CIF flue gas treatment filters.

- Optimize the zinc bromide-to-fuel oil and air ratio to ensure complete combustion of zinc bromide and minimize the production of zinc metal vapor.

- Since we can not assume a $100 \%$ efficiency in the conversion of bromine vapor into its salts during the addition of sodium hydroxide into the steam atomized scrubber system (neutralization of any acidic vapor carryover), some amounts of bromine and its gaseous derivatives will probable find their way into the CIF HEPA filters. Therefore, a way of removing these stray gases or carryovers must be developed.

- Evaluate the effects of and ways to minimize bromine corrosion. 


\section{REFERENCES}

(1) Walker B. W. and A. Wong "OCTF Test Report: HEPA Life Test Report Run 1-8 (U), SRT-WHM-95-0042, Dec. 1, 1995.

(2) Encyclopedia of Chemical Technology

Fourth Edition, Vol. 4, John Wiley \& Sons, NY, Editors Jacqueline I. Kroschwitz and Mary Howe-Grant.

(3) Cullis, C.F. Mirschler, M.M and Khattab,M.A.A.M "Mechanisms of Actions of Some Sulfates as Flame Retardants for Cellulose", European Polymer Journal, Vol. 26, No.2, Pg. 207-213 (1990).

(4) McNeill, I.C and R.C. McGuiness, "Effects of Zinc Bromide on the Thermal Degradation of Poly(Methyl Methacrylate): Part 2-Reaction Products..." Polymer Degradation and Stability, vol. 9, No. 4, pg. 209-224 (1984).

(5) Nouveau Traite de Chimie Minerale Tome V, Masson et C $C^{\text {ie }}$, Editeures, Paris (1962).

(6) Thermodynamic Constants of Inorganic and Organic Compounds M. Kh. Karapet'yants and M.L. Karapet'yants, Ann Arbor-Humphrey Science Publishers, Ann Arbor, London (1970).

(7) Thermodynamic Properties of the Elements, Advances in Chemistry Series, Vol. 18. Published by the American Chemical Society (1956). 


\section{APPENDIX A}

\section{SELECT PROPERTIES OF ZINC BROMIDE AND SOME COMBUSTION PRODUCTS}

Zinc Bromide

Solid zinc bromide is a very hygroscopic granular powder $(4,5,6,7)$.

Density $=4.219 \mathrm{~g} / \mathrm{cc}$ at $20{ }^{\circ} \mathrm{C}$

Heat of dissolution in water $=62.9 \mathrm{KJ}(15,030 \mathrm{cal}$. $)$

Solubility in water $=20.9$ miles/Liter at $25^{\circ} \mathrm{c}\left(447 \mathrm{~g} / 100 \mathrm{~mL}\right.$ at $20^{\circ} \mathrm{C}$ and $675 \mathrm{~g} / 100 \mathrm{~mL}$ in hot water)

Aqueous solution $\mathrm{pH} \approx 4.0$, Boiling point $=702{ }^{\circ} \mathrm{C}$, Melting point $=394{ }^{\circ} \mathrm{C}$.

The free energy, enthalpy and entropy of zinc bromide formation at $25^{\circ} \mathrm{C}$ are

respectively:

$\Delta G^{o}=-310 \mathrm{~kJ} / \mathrm{mole}(-74,089 \mathrm{cal} / \mathrm{mole})$

$\Delta H^{o}=-327.3 \mathrm{~kJ} / \mathrm{mole}(-78,234 \mathrm{cal} / \mathrm{mole})$

$\Delta S^{o}=-58.15 \mathrm{~J} /$ degree $\mathrm{C} / \mathrm{mole}(-13.90 \mathrm{cal} /$ degree $\mathrm{C} / \mathrm{mole})$.

Vapor pressure of solid zinc bromide is given by the following relationship: $\log \mathrm{P}_{\mathrm{mmHg}}$ $=-6614 / \mathrm{T}+9.697$, where $\mathrm{T}$ is temperature in degree centigrade. The average heat of sublimation between 240 and $310^{\circ} \mathrm{C}$ is $126.8 \mathrm{~kJ} / \mathrm{mole}(30,300 \mathrm{cal} / \mathrm{mole})$.

\section{Zinc Oxide/zinc Carbonate/Zinc Hydroxide}

Density of zinc oxide $=5.605 \mathrm{~g} / \mathrm{cc}$

Melting temperature of Zinc oxide $=1975{ }^{\circ} \mathrm{C}$

Solubility of zinc oxide $=$ fairly insoluble

Density of Zinc carbonate $=3.398 \mathrm{~g} / \mathrm{cc}$

Solubility of zinc carbonate $=$ fairly insoluble

$\mathrm{pH}$ of resulting "blowdown" $=$ acidic

$\begin{array}{lcccc} & \Delta H^{o}(\mathrm{~kJ} / \text { Mole }) & \Delta G^{o}(\mathrm{~kJ} / \mathrm{Mole}) & \Delta \boldsymbol{S}^{o}(\mathrm{~J} / \text { Mole }) & C_{p}\left(\mathrm{~J} / \mathrm{Mole}^{\circ} \mathrm{C}\right) \\ \mathrm{ZnCO}_{3} & -810.35 & -732.13 & 92.42 & - \\ \mathrm{ZnO} & - & -385.50 & 224.57 & 32.70 \\ \mathrm{Zn}(\mathrm{OH})_{2} & - & 554.53 & 83.22 & \\ \mathrm{Br}_{2} & 1,072.3 & - & 153.90 & \ldots\end{array}$

Bromine

Boiling point of bromine $=58.25^{\circ} \mathrm{C}\left(331.4^{\circ} \mathrm{K}\right)$.

Heat of vaporization of bromine at normal bp. $=29.985 \mathrm{~kJ} / \mathrm{gram}$ mole $(7,170 \mathrm{cal} / \mathrm{gram}$ mole).

Critical temperature $=310.85^{\circ} \mathrm{C}\left(584^{\circ} \mathrm{K}\right)$.

Critical pressure $=102$ atmosphere. 


\section{ZINC BROMIDE COMBUSTION: IMPLICATIONS FOR THE} CONSOLIDATED INCINERATOR FACILITY (U).

To: $\quad$ B.T.Butcher, 773-43A

From: L.N. Oji, 773-43A

\section{Distribution:}

W. E. Stevens, 773-A

W. B. Van Pelt, 679-T, Rm. 2AE

C.W. Mcray, 704-43H

M.G. Looper, 704-45H

M. J. Barnes, 773-A

H. L. Martin, 707-C

S. E. Crook, 261-4H

M. B. Birk, 261-5H 